\title{
STUDY THE EFFECT OF PARTIAL ROOTZONE DRYING IRRIGATION ON TOMATO CROP UNDER EGYPTIAN CONDITION
}

\author{
Gomaa, A. H ${ }^{(1)}$; A. A. Samak ${ }^{(2)}$ and E. H. Elshkhaby ${ }^{(3)}$
}

\begin{abstract}
Agriculture is the main user of water, because the agriculture uses about $85 \%$ of available freshwater resources worldwide. This percentage will continue to be dominant in water consumption because of population growth and increased food demand. In Egypt, agriculture uses more than $80 \%$ of the available water. In irrigated agriculture, the right way to save irrigation water is to increase water use efficiency through better irrigation management (Toureiro et al., 2016). Water management is the most significant element to increase crop productivity. There is an urgent need to create strategies based on science and technology for sustainable use of water, including technical, agronomic, managerial, and institutional improvements (Jury and Vaux, 2007). Worldwide, tomato is the second most valuable vegetable crop next to potato $(\boldsymbol{F A O}, 2018)$. In Egypt, tomato is one of the leading vegetable in economic importance. The present study was conducted in the farm of the agriculture faculty, Menoufia University, Shebin EL-Kom during two growing seasons (summer season 2015 and winter season 2016). The main goal of this study was to investigate the effect of the partial rootzone drying irrigation on soil moisture, tomato yield and water use efficiency. The study was carried out to compare partial rootzone drying and the conventional irrigation under three levels of water application rate $1100 \%, 75 \%$ and $50 \%$ of crop evapotranspiration, ET $T_{C}$ ), and covering conditions (covering and non-covering conditions). The partial rootzone drying irrigation and the covering condition increased the soil moisture content in soil profile, the percentage of marketable yield, and improved the water use efficiency compared with the conventional irrigation (CI) methods especially, when applying under deficit water application.
\end{abstract}

Key words: Conventional Irrigation, Partial Rootzone Drying, Tomato Plant, Water Use Efficiency, Deficit Water Application

\footnotetext{
(1) Professor, Agricultural Engineering Department, Menoufia University

(1) Lecturer, Agricultural Engineering Department, Menoufia University

(3) Agricultural engineering Institute, Agricultural Research Center.
} 


\section{INTRODUCTION}

7 he water shortage or scarcity can be defined as lack of water available in both quantity and quality for the use of the local population of a region. Water shortage is also referred as water scarcity. Widespread water shortages and future climate change predictions have demanded emphasis on improving water use efficiency (WUE) through defining critical plant water status parameters for precise and efficient water management (Anderson et al., 2008). According to Huffaker and Hamilton (2007), irrigated agriculture is the main user of the available water in the world. More than $70 \%$ of the total water withdrawals and 60-80 \% of total consumptive water use are consumed in irrigation. In the same time, the irrigation area is continuously increasing in order to meet the food demand of growing population, and in fragile ecological arid areas, additional water supply is important needed to increase food production in the coming decades (Kang and Zhang, 2004). In Egypt, tomato is one of the leading vegetable in economic importance. In 2008, tomato acreage in Egypt was 571844 Faddans. Yield

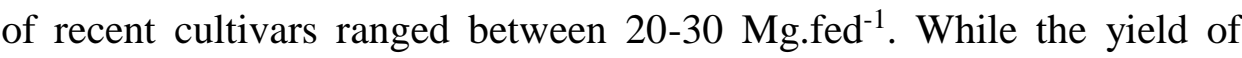
some hybrids may reach to 60-70 Mg.fed ${ }^{-1}$. Kirda, et al., (2004) reported that, the wetted and dry sides are the Partial Rootzone Drying Irrigation (PRDI) practice simply requires wetting of one half of the rooting zone and leaving the other half dry, thereby utilizing reduced amount of irrigation water applied. The wetted and dry sides are inter changed in the subsequent irrigations. Tang, et al., (2005) suggested that, alternative furrow irrigation is an effective water-saving irrigation method in arid area and plant vegetative growth can be controlled by the irrigation such that seed cotton yield can be maintained with less water but higher quality fibers. Lekakis et al., (2011) indicated that fixed partial rootzone drying irrigation (FPRD) application on both soils was capable of supplying sufficient amounts of water on plant row. Partial rootzone drip irrigation involves approximately half of the root system being irrigated normally, while the remaining half of the root system is exposed to drying soil. The wetted and dried sides of the root system are alternated. Fixed partial rootzone drying irrigation (FPRD) involves approximately half of the root system being irrigated normally, while the remaining half of the root 
system is exposed to drying soil during the completely growing season. So far there are many reports about (PRD) on physiology, growth, fruit yield and quality, and water use efficiency (WUE) of horticultural crops according to Zegbe-Domiguze et al., (2003), Kirda, et al., (2004), and Dorji et al., (2005). De la Hera, et al., (2007) found that, there was an positive effect on vegetative and reproductive growth when long-term partial rootzone drying irrigation was applied from the beginning of growing season, suggesting that early onset of partial rootzone drying irrigation is desirable to intensify partial rootzone drying irrigation response under these semi-arid conditions. Marjanović et al., (2015) found that, partial rootzone drying method is one of the irrigation methods with the potential to increase the water use efficiency and sustain the yield of many crops including tomato. Shahnazari et al., (2007) recommended that partial rootzone drying irrigation is effective watersaving irrigation strategy for potato production in areas with limited water resources. Taisheng et al., (2006) suggested that, alternatively furrows watered should be a useful water-saving irrigation regime in arid and semi-arid regions where cotton production is heavily dependent on irrigation and water resources are scarce. Wei et al., (2016) suggested that, partial rootzone drying irrigation, especially under drip irrigation have some potential to be used as an effective water-saving irrigation strategy in arid region of northwest China where tomato production is threatened by insufficient irrigation water for agriculture. Yactayo et al., (2013) found that, partial rootzone drying is an irrigation technique, which has shown increased water use efficiency (WUE) without yield reductions in potato and other crops. Yang et al., (2012) reported that, partial rootzone drying irrigation increased the ratio of sugar/acid and improved fruit quality greatly. However, fixed partial rootzone drying reduced fresh fruit yield and other quality parameters. Gencoglan et al., (2006) mentioned that, irrigation water saving and water-use reduction were found to be 16 and $13 \%$, respectively, without green bean yield or dry biomass reduction for subsurface drip irrigation and partial rootzone drying irrigation methods. De la Hera et al., (2007) found that, partial rootzone drying irrigation was higher than conventional irrigation in both yield (kg per vine) (43\%) and water use efficiency (40\%) compared to 
conventional irrigation vines. Spreer et al., (2007) found that, yield were reduced in deficit irrigation treatments when compared with the fully irrigated control. Development and post-harvest quality of fruits grown under deficit irrigation were not affected when the production of mango under regulated deficit irrigation was compared with full conventional irrigation. The irrigation methods were evaluated by their effect on yield and quality of mango fruits. Intrigliolo and Castel (2009) studied the effects of irrigation water amount and partial rootzone drying (PRD) on water relations, growth, yield, and quality of vine. The PRDI applied at two levels (100\% and $50 \%$ of the estimated crop evapotranspiration) were compared to conventional drip irrigation. They found out that the effects of irrigation water amount on yield and vine quality differed between the years. With low yield values for instance, irrigation affected neither grape production nor vine quality. In the following year, with a much higher general yield, the higher irrigation increased the must total soluble solids and vine alcohol content. Parvizi et al., (2016) mentioned that, partial rootzone drying irrigation using $75 \%$ of crop evapotranspiration (ETc) is recommended, applicable water-saving strategy and good alternative with respect to full irrigation among other irrigation managements when water resources are limited; in order to increase transpiration efficiency and water use efficiency while other physiological and growth parameters are maintained at an acceptable level. Wang et al., (2012) mentioned that water use efficiency (WUE) was the highest in partial rootzone drying irrigation, followed by deficit irrigation and the lowest in conventional irrigation; while $\mathrm{N}$-fertilization rate had no effect on WUE. El-Sadek (2014) confirmed an increase in irrigation water productivity using partial rootzone drying irrigation comparing with conventional flood irrigation. Wei et al., (2016) showed that, Partial Rootzone Drying Irrigation (PRD) usually had a higher water use efficiency improvements with no significant difference in yield, but $33.3 \%$ less irrigation water. The main objectives of this study were:

1. Evaluating the partial root-zone drying regime compared to the conventional irrigation under drip irrigation system on tomato crop under Egyptian conditions.

2. Studying the effect of using covering and non-covering conditions. 
3. Studying the effect of using different levels of deficit water application under two irrigation regimes.

4. Studying soil moisture status around the wetting area in rootzone, tomato yield and water use efficiency.

\section{MATERIALS AND METHODS}

\section{1. Experimental Site}

The present study was conducted in the experimental farm of the faculty of agriculture, Menoufia University at Shebin EL-Kom (17.9 m above sea level, $30^{\circ} 32 / \mathrm{N}$, and $\left.31^{\circ} 03 / \mathrm{E}\right)$ during summer season 2015 and winter season 2016. Tomato, (Lycopersion esculentum Mill.) seeds variety of Savera (F1 HYBRID TOMAYO) were planted on ridges $(0.7 \mathrm{~m}$ width and $15 \mathrm{~m}$ length) and the distance between plants inter-row was $0.5 \mathrm{~m}$. The distance between individual drippers was $0.5 \mathrm{~m}$ and emitter flow rate was 4 L.h ${ }^{-1}$.

Random soil samples from three soil layers, (at depths 0-30, 30-60, and $60-90 \mathrm{~cm}$ ) were collected from the experimental site and analyzed to state the soil physical properties and the soil chemical analysis (Black, 1965). Mechanical and chemical analysis of the soil samples showed that the soil texture is clay with field capacity of $31.5 \%$, soil welting point of $15.65 \%$ and soil bulk density of $1.30 \mathrm{gm} . \mathrm{cm}^{-3}$. The total soluble salts were measured as electrical conductivity (EC) and it was about $0.38 \mathrm{dsm}^{-1}$ as an average for the soil depth up to $90 \mathrm{~cm}$ and the value of $\mathrm{PH}$ was 7.73.

The chemical analysis of the irrigation water illustrated that the electrical conductivity value was about $0.37 \mathrm{dsm}^{-1}$ and the Sodium Absorption Ratio (SAR) value was about 1.06. Soil moisture content was determined using the following equation Casillas (1978):

$$
P_{w}=\frac{\left(W_{w}-W_{d}\right)}{W_{d}} \times 100=\left(\frac{W_{w}}{W_{d}}-1\right) \times 100
$$

Where: $\mathrm{P}_{\mathrm{W}}$ is the soil moisture content on (\% dry weight basis); $\mathrm{W}_{\mathrm{w}}$ is the wet weight of soil (gm), and $\mathrm{W}_{\mathrm{d}}$ is the dry weight of soil (gm).

\subsection{The Experimental Treatments}

The field experiment was conducted with changing three factors, which can be described as follows: 
1. Irrigation regime: two irrigation regimes (Conventional Irrigation (CI), and Partial Rootzone Drying Irrigation (PRD).

2. Amount of applied water: three levels were used $100 \%, 75 \%$, and $50 \%$ of crop evapotranspiration (ETc).

3. The covering conditions: Covering and non-covering conditions were concerned in this study. The experimental treatments are shown in Figure (1).

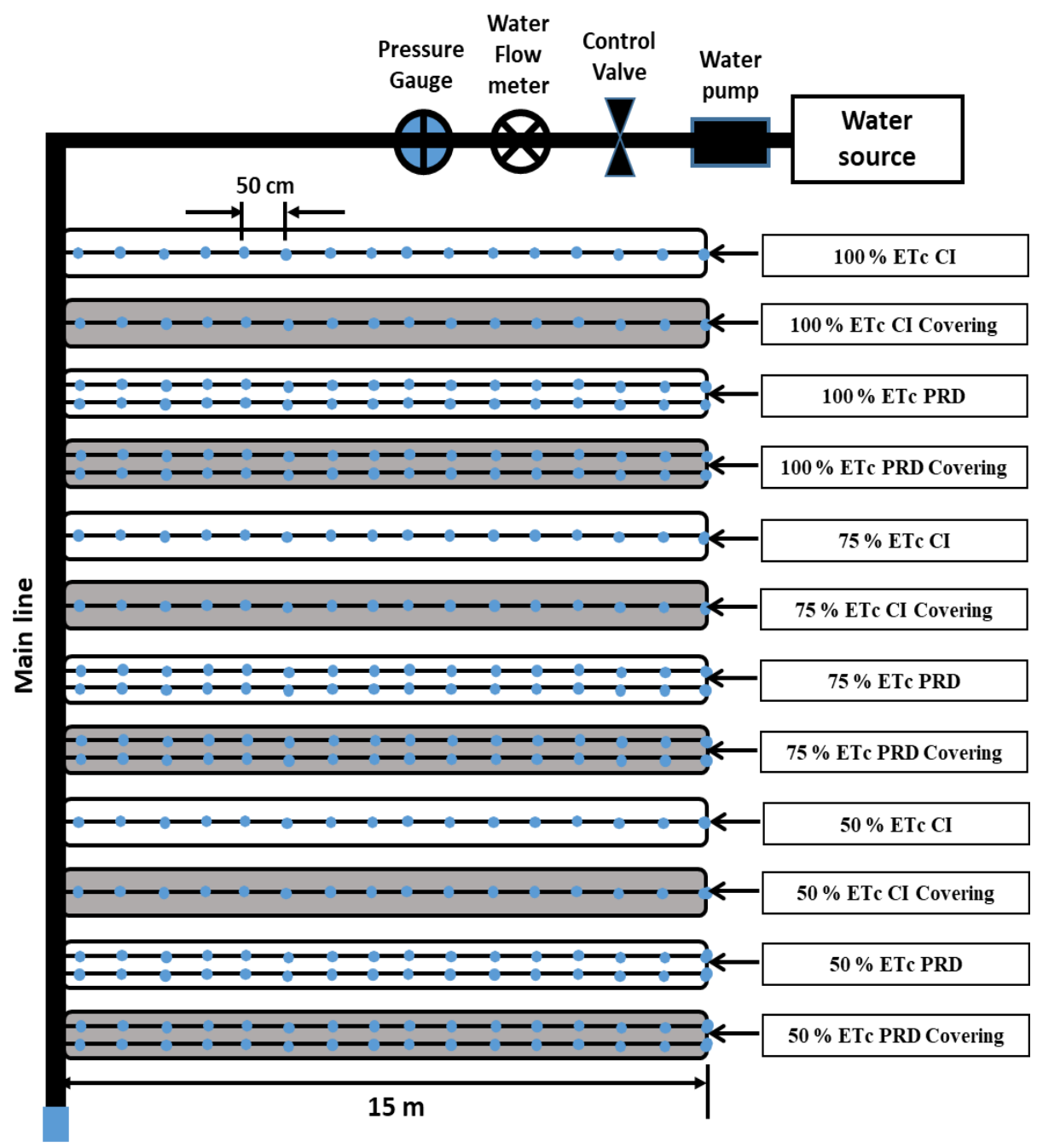

Figure (1): Experimental layout conducted in randomized design with three replicates. 


\subsection{Hydraulic Evaluation of Emitters:}

Hydraulic characteristics were carried out for the used long-path emitter with flow rate of $4 \mathrm{~L} \cdot \mathrm{h}^{-1}$. Emitter flow rate vs pressure curve was determined and expressed by the power curve equation as presented by Keller and Karmeli (1974):

$$
\boldsymbol{q}=\boldsymbol{K} \boldsymbol{P}^{X}
$$

Where: $\mathrm{q}$ is emitter discharge $\left(\mathrm{L} . \mathrm{h}^{-1}\right)$; $\mathrm{K}$ is constant of proportionality that characterizes each emitter; $\mathrm{P}$ is average of Pressure (bar); and $\mathrm{X}$ is emitter discharge exponent that is characterizes by the flow regime.

A separated experiment was conducted before field experiment to determine the manufacturing coefficient of variation $\left(\mathrm{C}_{\mathrm{V}}\right)$. Flow rate of 30 new emitters (as samples) were measured at reference uniform pressure (nominal operating pressure), and $\mathrm{C}_{\mathrm{V}}$ value was computed using the following equation Solomon (1987):

$$
C V=\frac{s}{\bar{q}}
$$

Where: $\mathrm{S}$ is the standard deviation of flow rate values $\left(\mathrm{L} \cdot \mathrm{h}^{-1}\right)$ at reference pressure; and $\mathrm{q}^{-}$is average flow rate of the emission points sampled (L.h ${ }^{-}$ 1).

Emission uniformity (EU) of lateral line was determined in the field by using EU test, which determined by measuring, under normal conditions, the pressure at the inlet and at the far end of each lateral. Emission uniformity (EU) was calculated using the following equation Keller and Karmeli (1975):

$$
E U=100\left(1-\frac{1.27 C_{v}}{\sqrt{e}}\right) \frac{q_{m}}{q_{a v}}
$$

Where: $\mathrm{C}_{\mathrm{V}}$ is the manufacture coefficient of variation (\%); e is the number of emitter per plant; $\mathrm{q}_{\mathrm{m}}$ is the minimum emitters discharges (L.h ${ }^{-}$ ${ }^{1}$ ); and $\mathrm{q}_{\mathrm{av}}$ is the average emitter discharge $\left(\mathrm{L} \cdot \mathrm{h}^{-1}\right)$.

\subsection{Water Use Efficiency (WUE)}

Tomato fruits were harvested manually, and total crop yield per feddan $\left(\mathrm{Mg} . f e d^{-1}\right)$ was recorded. Water use efficiency (WUE) was calculated for each treatment by using the total obtained yield and total seasonal water 
applied. This parameter is considered as an economic factor which can be used to compare between studied treatments. Irrigation water use efficiency (WUE) was calculated using the following equation (Jensen, 1983):

$$
W U E=\frac{Y}{I}
$$

Where: WUE is irrigation water use efficiency $\left(\mathrm{Kg}^{\left.-\mathrm{m}^{-3}\right)}\right.$; $\mathrm{Y}$ is total yield $\left(\mathrm{Kg}_{\mathrm{fed}}{ }^{-1}\right)$, and I is applied irrigation water $\left(\mathrm{m}^{3} \cdot \mathrm{fed}^{-1}\right)$.

\section{RESULTS AND DISCUSSIONS \\ 3.1. Hydraulic characteristics of emitter}

The effect of pressure on the long-path emitter was studied. The influence of pressure on the emitter discharge can be presented in two ways either directly as the average of emitter discharge as shown in Figure (2) or as variable percentage of discharge at the same actual operating pressure of one bar.

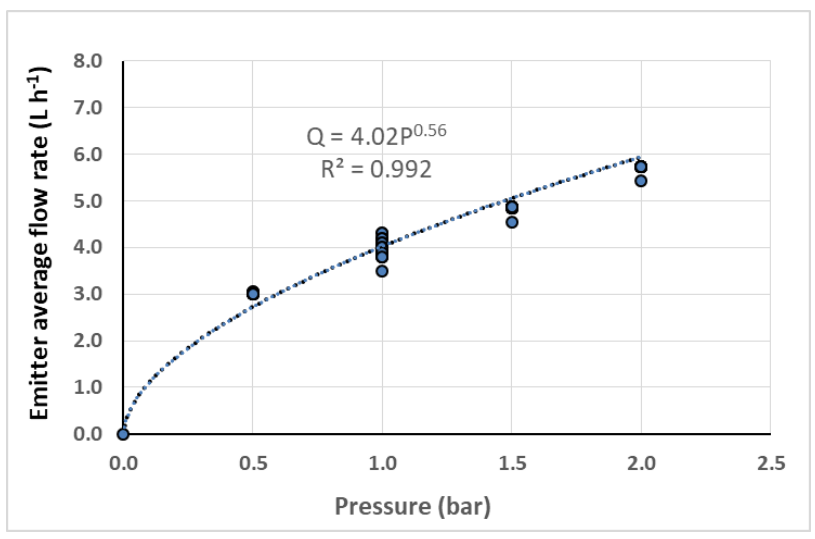

Figure (2): Pressure-discharge curve of the long-path emitter of 4 L.h ${ }^{-1}$ nominal flow rate.

The results showed that, the relationship between the pressure and the discharge of the long-path emitter of $4 \mathrm{~L} . \mathrm{h}^{-1}$ flow rate could be expressed as the following equation:

$$
q=4.02 P^{0.56}
$$

Where: $\mathrm{q}$ is the average emitter discharge $\left(\mathrm{L} \cdot \mathrm{h}^{-1}\right)$, and $\mathrm{P}$ is the average operating pressure (bar) 
The equation showed that, the exponent of the operating pressure was approximately equal to 0.56 , which means that in this case, the flow was turbulent and is less sensitive to pressure variation.

\subsection{Emission Uniformity (EU) and Coefficient of Manufacturing Variation (CV)}

The Emission uniformity (EU) and coefficient of manufacturing variation (CV) for the tested long-path emitter are calculated. The results showed that, the value of emission uniformity for the studied emitter was about $99.45 \%$ at the operating pressure of one bar and the average emitter discharge of $4{\mathrm{~L} . \mathrm{h}^{-1}}^{-}$. This value seemed to achieve the higher emission uniformity. Coefficient of manufacturing variation $(\mathrm{CV})$ varied according to the operating pressure. The data showed that, the value of manufacturing coefficient $\left(\mathrm{CV}_{\mathrm{V}}\right)$ was $0.5 \%$. The lower value of manufacturing coefficient of variation reflexed the higher uniform distribution of irrigation water along the lateral line. The emitter achieved uniform distribution of water at one bar of operating pressure at which the drip irrigation system will be operated in the field.

\subsection{Soil Moisture Content}

Figure (3) revealed that the average of the soil moisture content using two irrigation regimes under different amount of applied water during the winter season 2016. Considering the covering and non-covering conditions the results showed that, the $100 \%$ ETc recorded the higher value, followed $75 \% \mathrm{ETc}$ and finally $50 \% \mathrm{ETc}$. The PRD regime was higher than CI treatment under all levels of the applied amount of water. The results reported that, the PRD treatment was higher than CI treatment by $3.44 \%, 2.95 \%$ and $2.36 \%$ for $100 \%$ ETc, $75 \%$ ETc and $50 \%$ ETc respectively with covering condition. Meanwhile, under non-covering condition, the PRD treatment was higher than CI treatment by $3.03 \%$, $2.56 \%$ and $2.16 \%$ for $100 \%$ ETc, $75 \%$ ETc and $50 \%$ ETc respectively. However, under CI irrigation treatment the results showed that, the covered system recorded the higher value compared to non-covered by $5.80 \%, 7.66 \%$ and $8.05 \%$ for $100 \%$ ETc, $75 \%$ ETc and $50 \%$ ETc respectively. Meanwhile the results of PRD treatment reported that, the 
covering condition was higher than non-covering by $6.20 \%, 8.20$ and $8.24 \%$ for $100 \% \mathrm{ETc}, 75 \% \mathrm{ETc}$ and $50 \mathrm{ETc}$ respectively. These results are in agreement with the results reported by Hutton and loveys (2011).

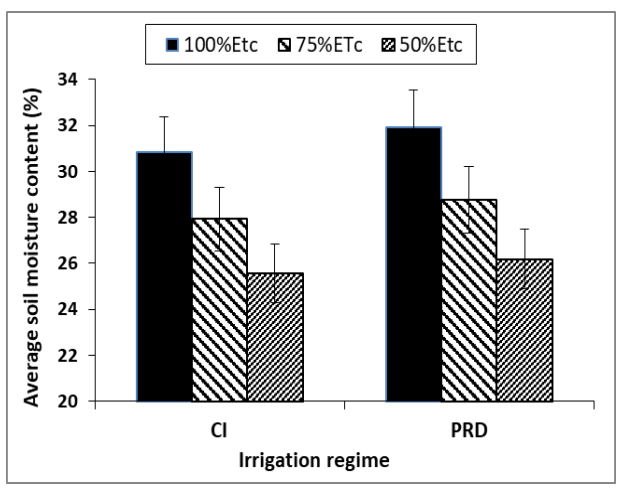

(a) covering condition

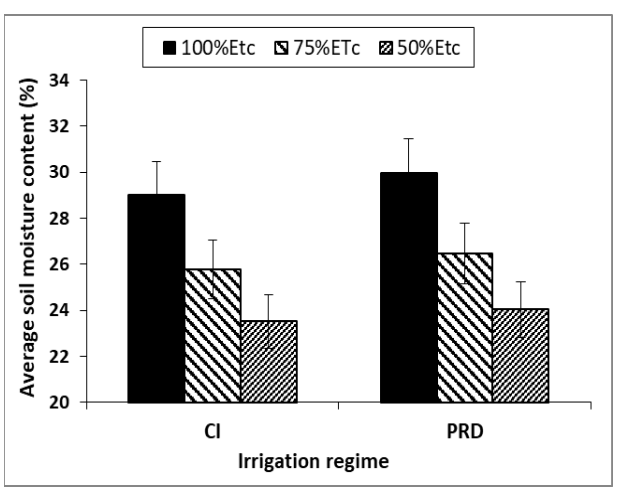

(b) non-covering condition

Fig (3): Average soil moisture content using two irrigation regimes under different amount of applied water during the winter season 2016.

\subsection{Tomato Yield}

The results of tomato yield showed that, increasing the amount of applied water from $50 \%$ ETc to $100 \%$ ETc gradually increased the obtained yield of tomato. In addition, the PRD treatment produced a higher yield compared with CI treatment. Table (1) showed the obtained yield of tomato using two irrigation regimes under the tested amount of applied water in summer season 2015 and winter season 2016. The results under covering condition showed that, $75 \%$ of ETc produced a higher yield, followed $100 \%$ of ETc and $50 \%$ of ETc. The PRD treatment was higher than CI treatment by $8.81 \%$ at $75 \%$ of ETc. Meanwhile, under noncovering condition, $100 \%$ of ETc produced the highest value. The PRD treatment was higher than CI treatment by $4.71 \%, 11.86 \%$ and $17.92 \%$ at $100 \%$ of ETc, $75 \%$ of ETc and $50 \%$ of ETc respectively. The results of $\mathrm{CI}$ treatments under covering condition was higher than the non-covering by $11.25 \%$ and $20.84 \%$ at $75 \%$ of ETc and $50 \%$ of ETc respectively. However, with $100 \%$ of ETc, the covering condition was lower than the non-covering by $11.70 \%$. 
Table (1): Tomato yield using two irrigation regimes under the tested amount of applied water for summer season 2015 and winter season 2016.

\begin{tabular}{|c|c|c|c|c|c|c|c|c|c|c|c|c|}
\hline \multicolumn{13}{|c|}{ Tomato yield (Mg.fed $\left.{ }^{-1}\right)$} \\
\hline \multirow{3}{*}{ 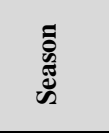 } & \multicolumn{6}{|c|}{ Covering } & \multicolumn{6}{|c|}{ Non-covering } \\
\hline & \multicolumn{2}{|c|}{$100 \%$ ETc } & \multicolumn{2}{|c|}{ 75\% ЕTс } & \multicolumn{2}{|c|}{$50 \%$ ETc } & \multicolumn{2}{|c|}{$100 \%$ ETc } & \multicolumn{2}{|c|}{$75 \%$ ETc } & \multicolumn{2}{|c|}{$50 \%$ ETc } \\
\hline & CI & PRD & CI & PRD & CI & PRD & CI & PRD & CI & PRD & CI & PRD \\
\hline $\begin{array}{c}\text { Summer } \\
2015\end{array}$ & 30.06 & 31.94 & 31.98 & 35.07 & 26.15 & 30.09 & 33.58 & 35.24 & 28.38 & 32.20 & 20.70 & 25.22 \\
\hline $\begin{array}{c}\text { Winter } \\
2016\end{array}$ & 42.73 & 68.66 & 36.97 & 61.68 & 33.29 & 56.53 & 39.20 & 44.15 & 29.70 & 37.62 & 24.53 & 33.91 \\
\hline
\end{tabular}

The results of PRD treatments under covering condition produced the higher value compared with the non-covering by $8.18 \%$ and $16.18 \%$ at $75 \%$ of ETc and $50 \%$ of ETc respectively. However, under $100 \%$ of ETc, the covering treatment produced the lower value compared with the noncovering by $9.36 \%$. The results of winter season 2016 showed that, under covering treatments, the $100 \%$ of ETc produced a higher yield, followed $75 \%$ of ETc and $50 \%$ of ETc. The PRD treatment was higher than CI treatment by $37.76,40.06$ and $41.11 \%$ for $100 \%$ of ETc, $75 \% \mathrm{ETc}$ and $50 \%$ of ETc respectively. Meanwhile, under non-covering treatments, the PRD treatment was higher than CI treatment by $11.21 \%, 21.05 \%$ and $27.66 \%$ at $100 \%$ of ETc, $75 \%$ of ETc and $50 \%$ of ETc respectively. Moreover, the results of $\mathrm{CI}$ treatments illustrated that, the covering condition was higher than the non-covering by $8.26 \%, 19.66 \%$ and $26.31 \%$ at $100 \%$ of ETc, $75 \%$ of ETc and $50 \%$ of ETc respectively. Nevertheless, the results of PRD treatments clarified that, the covering treatment produced the higher value compared with the non-covering treatment by $35.69 \%, 39 \%$ and 39.98 with $100 \%, 75 \%$, and $50 \%$ of ETc respectively. The PRD irrigation regime resulted the highest value compared with CI, because the average weight of the individual fruit weight was increased. This reason might be the same which mentioned by Kirda et al., (2004). They reported that the PRD irrigation regime had 7 to $10 \%$ additional yield over the deficit irrigation receiving the same amount of water. The PRD irrigation regime resulted 10 to $27 \%$ higher marketable tomato yield ( $>60 \mathrm{gm} /$ per plant), compared with the deficit irrigation regime. 


\subsection{Dry matter content of tomato fruits}

The results of dry matter content of tomato fruits are listed in Table (2). The results of summer season 2015 showed that, the PRD treatment was higher than CI treatment under all amount of applied water. The data of dry matter content of tomato fruits noticed that, when deficit amounts of water were applied the percent of dry matter of tomato fruits increased. The water amount of 50\% ETc resulted the highest value followed $75 \%$ ETc, finally $100 \%$ ETc. There was a difference between the two irrigation regimes, but it was not significant. The results of summer season 2015 showed that, the dry matter content of tomato fruits under non-covering condition was higher than covering condition. Under covering condition, the highest value of dry matter of tomato fruits was $5.90 \%$ and $5.84 \%$ for PRD and CI respectively with $50 \%$ of ETc. Meanwhile, under noncovering condition, the greatest value of dry matter of tomato was $7.89 \%$ and $7.02 \%$ for PRD and CI respectively with $50 \%$ of ETc. Moreover, the results of winter season 2016 showed that, under covering condition, the dry matter content of the PRD was higher than CI under $50 \%$ of ETc. Meanwhile, under non-covering condition, the PRD was higher than CI under $50 \%$ of ETc. The results of dry matter of tomato fruits showed that, the PRD irrigation regimes recorded the lowest value compared with CI, because tomato plants are sensitive to water deficit during flowering and fruit set, so flower abortion might occurred. Meanwhile, dry matter content of tomato fruits improves under PRD compared with CI. Increasing the dry matter content of tomato fruits improves its quality because the high matter content considered a remarkable parameter for processing due to low energy required for processing.

Table (2): Dry matter content of tomato fruits under two irrigation regimes and different amount of applied water for summer season 2015 and winter season 2016.

\begin{tabular}{|c|c|c|c|c|c|c|c|c|c|c|c|c|}
\hline \multicolumn{13}{|c|}{ Fruit dry matter content (\%) } \\
\hline \multirow{3}{*}{ 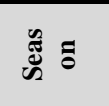 } & \multicolumn{6}{|c|}{ Covering } & \multicolumn{6}{|c|}{ Non-covering } \\
\hline & \multicolumn{2}{|c|}{$100 \%$ ETc } & \multicolumn{2}{|c|}{$75 \%$ ETc } & \multicolumn{2}{|c|}{ 50\%ETc } & \multicolumn{2}{|c|}{$100 \%$ ETc } & \multicolumn{2}{|c|}{$75 \%$ ETc } & \multicolumn{2}{|c|}{ 50\%ETc } \\
\hline & CI & PRD & CI & PRD & CI & PRD & CI & PRD & CI & PRD & CI & PRD \\
\hline $\begin{array}{c}\text { Summer } \\
2015\end{array}$ & 5.48 & 5.61 & 5.54 & 5.63 & 5.84 & 5.90 & 6.10 & 6.30 & 6.46 & 6.68 & 7.02 & $\mathbf{7 . 8 9}$ \\
\hline $\begin{array}{c}\text { Winter } \\
2016\end{array}$ & 4.81 & 4.93 & 5.64 & 5.73 & 6.37 & 6.70 & 5.93 & 6.25 & 6.53 & 6.82 & 8.22 & 7.44 \\
\hline
\end{tabular}




\subsection{Water Use Efficiency (WUE)}

Water use efficiency considered a remarkable differentiation parameter that was affected by the variation of the studied factors. Water use efficiency depends on both yield and the water applied. The data listed in Table (3) showed that, water use efficiency with the covering condition was higher than with the non-covering condition. The PRD irrigation regime recorded higher values of water use efficiency than CI treatment under all amount of applied water. Decreased the amount of water resulted increased the water use efficiency.

Table (3): The calculated water use efficiency $\left(\mathrm{Kg} \mathrm{m}^{-3}\right)$ as affected by the studied treatments.

\begin{tabular}{|c|c|c|c|c|c|c|c|c|c|c|c|c|}
\hline \multicolumn{13}{|c|}{ Water Use Efficiency $\left(\mathrm{Kg}_{\mathrm{g}} \mathrm{m}^{-3}\right)$} \\
\hline \multirow{3}{*}{ 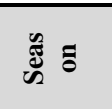 } & \multicolumn{6}{|c|}{ Covering } & \multicolumn{6}{|c|}{ Non-covering } \\
\hline & \multicolumn{2}{|c|}{ 100\%ETc } & \multicolumn{2}{|c|}{$75 \%$ ETc } & \multicolumn{2}{|c|}{ 50\% ETc } & \multicolumn{2}{|c|}{ 100\%ETc } & \multicolumn{2}{|c|}{$75 \%$ ETc } & \multicolumn{2}{|c|}{$50 \%$ ETc } \\
\hline & CI & \begin{tabular}{|l|} 
PRD \\
\end{tabular} & CI & PRD & CI & PRD & CI & PRD & CI & PRD & CI & PRD \\
\hline $\begin{array}{c}\text { Summer } \\
2015\end{array}$ & 5.04 & 5.67 & 7.28 & 8.31 & 9.29 & 10.70 & 5.34 & 5.97 & 6.72 & 7.63 & 7.36 & 8.97 \\
\hline $\begin{array}{c}\text { Winter } \\
2016 \\
\end{array}$ & 8.89 & 14.29 & 10.26 & 17.12 & 13.86 & 20.87 & 8.16 & 9.19 & 8.24 & 10.44 & 10.21 & 14.12 \\
\hline
\end{tabular}

The obtained data during summer season 2015 in Table (3) clarified that, the PRD treatment was higher than CI treatment by $11.11 \%, 12.39 \%$ and $13.17 \%$ for $100 \%, 75 \%$, and $50 \%$ of ETc respectively under covering condition. Moreover, the results of CI irrigation regime treatments showed that, the $50 \%$ of ETc was higher than both $100 \%$ and $75 \%$ of ETc by $45.74 \%$ and $21.63 \%$ respectively. In addition, for the PRD treatments, $50 \%$ of ETc recorded the higher value compared with $100 \%$ and $75 \%$ of ETc by $47.00 \%$ and $22.33 \%$ respectively. Meanwhile, under non-covering condition treatments, it was found that the PRD treatment was higher than the CI treatment by $10.55 \%, 11.92 \%$ and $17.94 \%$ for $100 \%, 75 \%$, and $50 \%$ of ETc respectively. The obtained results during winter season 2016 showed that, the PRD irrigation regime treatment was higher than CI treatment by $37.78 \%, 40.07 \%$ and $33.58 \%$ for $100 \%, 75 \%$, and $50 \%$ of ETc under covering condition treatments. Considering the irrigation regimes, under the CI treatments, the WUE with 50\% of ETc was higher than both $100 \%$, and $75 \%$ of ETc by $35.85 \%$ and $25.97 \%$ respectively. In additions, under the PRD treatments, the WUE with 50\% of ETc recorded the higher value compared with $100 \%$, and $75 \%$ of ETc by $31.52 \%$ and 
$17.96 \%$ respectively. Meanwhile, under non-covering conditions treatments, the PRD treatment was higher than CI treatment by $11.20 \%$, $21.07 \%$ and $27.69 \%$ for $100 \%, 75 \%$, and $50 \%$ of ETc respectively. Hence, comparing between the two irrigation regimes concluded the PRD irrigation regime treatment due to achieve the optimum value of water use efficiency (WUE) under the same amount of applied water and covering conditions. For all treatment, (WUE) increased with decreasing amount of applied water. These results are in agreement with the results obtained by Wang et al., (2012). They found that, Water use efficiency (WUE) was higher in case of PRD irrigation regime, followed by deficit irrigation and the full irrigation.

\section{CONCLUSION}

The flow characteristics of the long-path (GR) emitter was determined by the relation " discharge- pressure " as follow:

$$
q=4.02 P^{0.56}
$$

The optimum operating pressure, at which $\mathrm{CV}$ was smallest for long-path emitter was one bar. The value of emission uniformity for emitter was recorded $95.45 \%$ at one bar of the operating pressure with $4 \mathrm{~L} \mathrm{~h}^{-1}$ of the average emitter discharge. The best uniform distribution of soil moisture content in rootzone observed with the PRD irrigation regime. Tomato yield increased with increasing soil moisture content. During the summer season 2015 with PRD treatment, the highest value of tomato yield was $35.24 \mathrm{Mg} \mathrm{ha}^{-1}$ for $100 \%$ of ETc under non-covering condition. In addition, during the winter season 2016 with PRD treatment, the highest value was $68.66 \mathrm{Mg} \mathrm{ha}^{-1}$ for $100 \%$ of ETc under covering condition. Meanwhile, during the summer season with PRD treatment, the highest value of water use efficiency was $10.70 \mathrm{~kg} \mathrm{~m}^{-3}$ for $50 \%$ of ETc under covering condition. Moreover, during the winter season 2016 with PRD treatment, the highest value of water use efficiency was $20.87 \mathrm{~kg} \mathrm{~m}^{-3}$ for $50 \%$ of ETc under covering condition.

\section{REFERENCES}

Anderson. K; C. Findlay; S. Fuentes; and S. Tyerman, (2008). Viticulture, Wine and Climate Change. Garnaut Climate Change Review. 
Black, C.A. (1965). Method of soil and water analysis. Part 2: Madison, Wisconsin, USA.

Casillas, G. (1978). Soil water engineering laboratory manual, Colorado State. University. Dep. of Agri. and Chem. Eng. Fort Collins, Colorado 80523, June 19.

De la Hera. M.L; P. Romero; E. Gomez-Plaza; and A. Martinez (2007). Is partial root- zone drying an effective irrigation technique to improve water use efficiency and fruit quality in field- grown wine grapes under semiarid conditions? Agriculture water management 87 (2007) 261- 274.

Dorji, K; M.H. Behboudian; and J.A. Zegbe-Domınguez (2005). (Water relations, growth, yield, and fruit quality of hot pepper under deficit irrigation and partial rootzone drying) Scientia Horticulture 104 (2005) 137-149.

El-Sadek. A. (2014). Water use optimization based on the concept of Partial Rootzone Drying. 1016/j.asej.2013004" HYPERLINK "http://dx.doi.org/10.1016/j.asej.2013.09.004"AinHYPERLINK "http://dx.doi.org/10.1016/j.asej.2013.09.004" Shams Engineering Journal (2014) 55-62.

FAO (2018). FAOSTAT online database, available at link http://faosstat.Fao.org/. Accessed on March 2018.

Gencoglan. C; H. Altunbey; and S. Genc, (2006). Response of green bean (P. vulgaris L.) to subsurface drip irrigation and partial Rootzone drying irrigation. Agriculture water management .48 (2006) 274280.

Huffaker, R and J. Hamilton (2007). Conflict. In: Irrig. Of Agri crops (Lascano. R.J; and Sojka. R.E. Ed.). Second edition Agronomy Monograph no.30. ASA- CSSA-SSSA publishing, 664p.

Hutton. R. J and B.R. loveys, (2011). A partial root zone drying irrigation strategy for citrus-Effects on water use efficiency and fruit characteristics. Agriculture water management. Volume 98, Issue 10, August 2011, Pages 1485-1496.

Intrigliolo, D. S; and J. R. Castel, (2009). Response of Vitis vinifera cv. 'Tempranillo' to partial rootzone drying in the field: Water 
relations, growth, yield, fruit, and wine quality. Agricultural water management (96): $282-292$.

Jensen, M.E, (1983). Design and operating of farm irrigation system. ASAE, Michigan, USA.

Jury, W. A. and H.J. Vaux (2007). The Emerging Global Water Crisis: Managing Scarcity and Conflict between Water Users. Advances in Agronomy (95): 1-76. https://doi.org/10.1016/S00652113(07)95001-4

Kang, S. Z, and J. Zhang (2004). Controlled alternate partial root-zone irrigation: its physiological consequences and impact on water use efficiency. J. Exp. Bot. 55, 407, 2437- 2446.

Keller. J. and D. Karmeli, (1974). Trickle irrigation design parameters. ASAE Transactions, 17 (4): 678-684.

Keller. J. and D. Karmeli, (1975). Trickle irrigation design. First Ed., Rain Bird Co., Glendora, CA: 133 pp.

Kirda C.C; M. Cetin; Y. Dasgan; S. Topcu; H. Kaman; B. Ekici; M.R. Derici; and A.I. Ozguven, (2004). Yield response of Greenhouse grown tomato to partial root drying and conventional deficit irrigation. Agricultural Water Management 69 (2004) 191-201.

Lekakis, E.H; P.E. Georgiou; A. Pavlatou-Ve; and V.Z. Antonopoulos (2011). Effects of fixed partial root-zone drying irrigation and soil texture on water and solute dynamics in calcareous soils and corn yield. Agricultural Water Management 101 (2011) 71-80.

Marjanović M; Z. Jovanovic; R. Stikic; and B.V. Radović (2015). The Effect of Partial Root-Zone Drying on Tomato Fruit Growth. Procedia Environmental Sciences 29 (2015) 87.

Parvizi .H; A.R. Sepaskhah; and S.H. Ahmadi, (2016). Physiological and growth responses of pomegranate tree (Punicagranatum (L.) cv. Rabab) under partial root zone drying and deficit irrigation regimes. Agricultural Water Management 163 (2016) 146-158.

Shahnazari, A; L. Fulai; N. A. Mathias; S. Jacobsen; and C.R. Jensen, (2007). Effects of partial root-zone drying on yield, tuber size and water use efficiency in potato under field conditions. Field conditions. Field Crops Research 100 (2007) 117-124. 
Solomaon. K. H, (1987). Selection of trickle irrigation emitters. In: Micro irrigation methods and materials update (eds. D. F. Zoldoske and M. Y. Miyaski), P.259- 256. Center for irrigation technology, Calif. Univ., Frenso, Calif. USA. Technology, choices: a micro parameter approach. Am. J. Agric. Econ. 78, 1064-1072.

Spreer. W; M. Nagle; S. Neidhart; R. Carle; S. Ongprasert, and J. Mueller (2007). Effect of regulated deficit irrigation and partial rootzone drying on the quality of mango fruits (Mangifera indica L., cv. 'Chok Anan').Agriculture water management 88 (2007) 173180.

Taisheng. Du; S. Kang; J. Zhang, Li. Fusheng; and Hu. Xiaotao, (2006). (Yield and physiological responses of cotton to partial root-zone irrigation in the oasis field of China) Agriculture water management (84): 41-52.

Tang. Li; Y. Li, and J. Zhang (2005). Physiological and yield responses of cotton under partial rootzone irrigation. Field Crops Research 94 (2005) 214-223.

Toureiro, C., Serralheiro, R., Shahidian, S., and Sousa, A. (2016). 'Irrigation management with remote sensing: Evaluating irrigation requirement for maize under Mediterranean climate condition'.

Agric. Water Manage. http://dx.doi.org/10.1016/j.agwat.2016.02.010

Wang, Z; F. Liu; S. Kang; and C.R. Jensen, (2012). Alternate partial rootzone drying irrigation improves nitrogen nutrition in maize (Zea mays L.) leaves. Environmental and Experimental Botany 75 (2012) 36-40.

Wei. Z; T.D; J. Zhang; S. Xu; P.J. Cambre, and W.J. Davies (2016) Cabron isotope discrimination shows a higher water use efficiency under alternate partial rootzone irrigation of field -grown tomato. Agriculture Water Management 165 (2016) 33-43.

Yactayo. W; D.V. Ramírez; R. Gutiérrez; V. Mares; A. Posadas, and Quiroz (2013). Effect of partial root-zone drying irrigation timing on potato tuber yield and water use efficiency. Agricultural Water Management 123 (2013) 65-70.

Yang. L; Qu. Hui; Y. Zhang; and Li. Fusheng (2012). Effects of partial root- zone irrigation on physiology, fruit yield and quality and 
water use efficiency of tomato under different calcium levels. Agricultural Water Management 104 (2012) 89-94.

Zegbe J.A; M.H. Behboudian; A. Lang; and B.E. Clothier (2003). Deficit irrigation and partial rootzone drying maintain fruit dry mass and enhance fruit quality in 'Petopride' processing tomato (Lycopersicon esculentum, Mill.) Sci. Horti. (98): 505- 510.

\section{الملخص العربي \\ دراسة تأثير الري الجزئي على محصول الطماطم تحت الظروف المصرية}

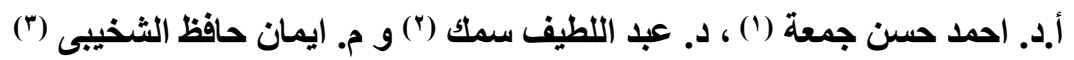

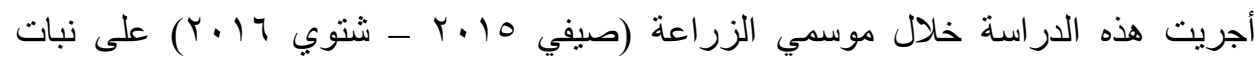

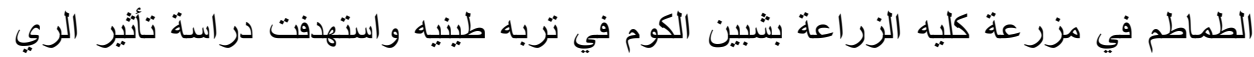

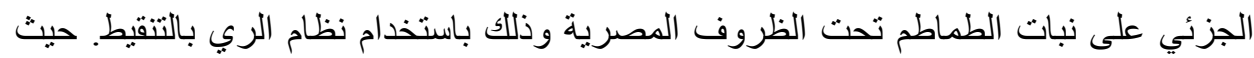

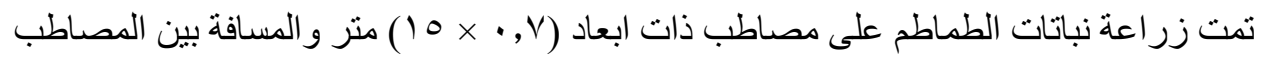

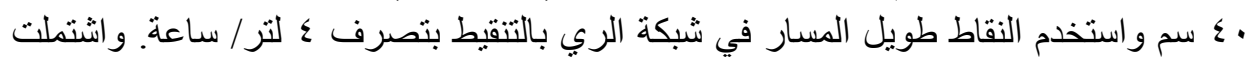

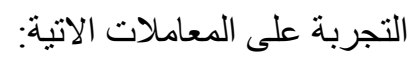

ا. نظام الري: تمت التجربة تحت نظامين للري وهما الري بالتنقيط التقليدي-الري بالتنقيط

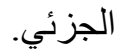

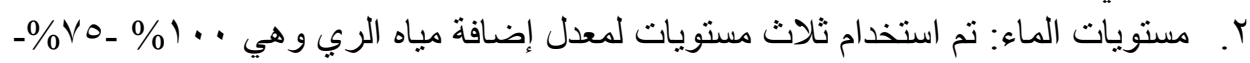

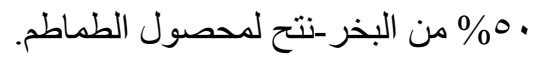
r. نظام التغطية: نم اجر اء التجربة وذللك باستخدام التغطية-وبدون استعمال التغطية بالبلاستيك.

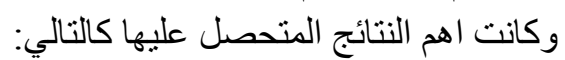

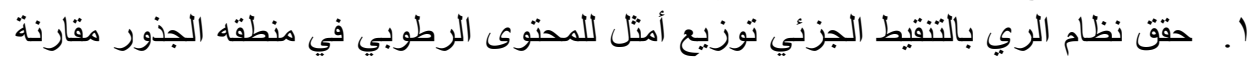

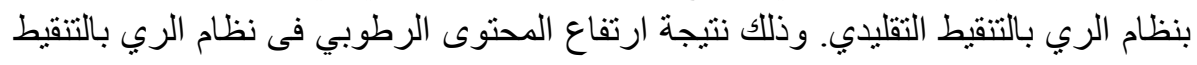

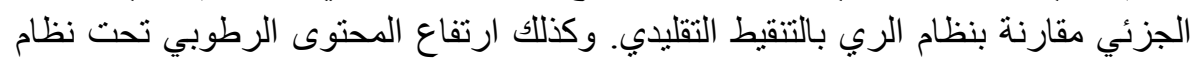
التغطية بالبلاستيك مقارنة بنظام عدم التئية التغطية.

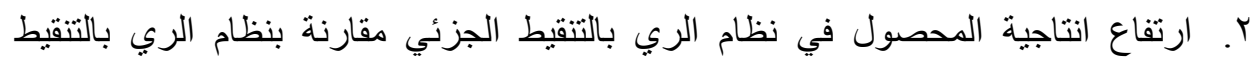

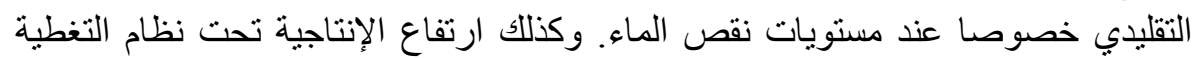

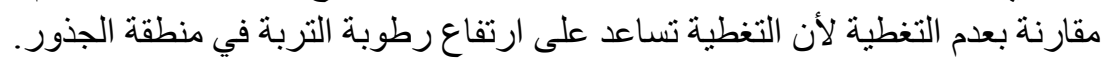

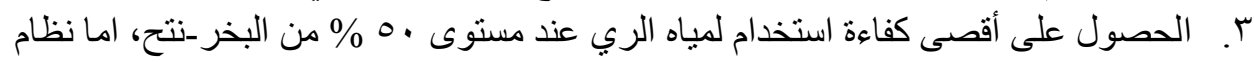

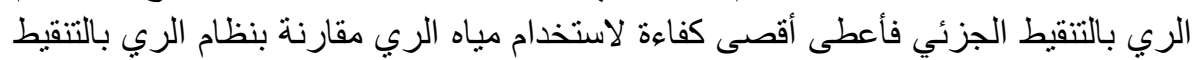

